\title{
Comparison of Social Stratification Theories between Marx and Weber
}

\section{Song Daoxin}

China Railway Construction Engineering Group Co., Ltd, China

Received: 11 Oct 2020; Received in revised form: 12 Nov 2020; Accepted: 13 Nov 2020; Available online: 18 Nov 2020

\begin{abstract}
As two giants of classical sociology, Marx and Weber have made great contributions in the field of social stratification, the content of which discussed by the two scholars not only play an important role at that time but also bring inspiration to later sociologists. In modern society, however, because the invisible social stratum still exists and has a positive or negative impact on all aspects of people's lives, analysis and comparison of social stratification theories by the two scholars are still of current significance.

For exploring theories of social stratification by Marx and Weber, I will compare the differences and similarities between the two scholars' theoretical research in the field of social stratification. After all is done, it is delighted for me to find that their ideological sources could be enlightenment for us to understand modern society better.
\end{abstract}

Keywords-Social Stratification Theories, Marx, Weber.

\section{THE DIFFERENCES}

\subsection{The standard for social stratification}

\subsubsection{Marx: Dichotomy}

For social stratification, Marx adopts a single standard of division, defining whether or not to possess the means of production and how much to possess (i.e. economic basis) as the principle. "He used 'class' to divide the social member's ownership and the social level in which he belongs to, and thus his social power is often referred to the class stratification paradigm” (盧满华\&卜晓勇,2017). Meanwhile, Marx believes that due to the differences of possessing production materials in the production process, the society is increasingly divided into two opposing classes: the bourgeoisie and the proletariat. And capitalist society is a bipolar society, despite the existence of an intermediate class, it will certainly belong to the bourgeoisie or the proletariat over time, so society will return to the situation -'two levels of opposition' again.

\subsubsection{Weber: Multidimensional Standard}

Compared to Marx's simpler stratum division criteria, Weber adopted multidimensional criteria based on 'market'.
That is, social stratification based on three dimensions -"Economical order, Social order, and Political order" (Bottero, 2005). “An individual's stratification position depends on their overall location in all three orders, but their class, status and party positions may not be identical" (Bottero, 2005).

\subsubsection{Economic Order: Class}

Like Marx, Weber also affirmed that 'economy' is a prior factor in the distinction of class, but the difference is that "Weber does not base on the production relationship which can be regarded as the ownership of the means of production class, but from the way of utilizing market opportunities to get wealth and income to divide classes" (㲊满华\&卜晓勇, 2017).

\subsubsection{Social Order: Status}

The concept 'status' is embodied in the humanist methodology of Weber. Weber believes that 'status' is a comprehensive product that reflects the characteristics of 'person' based on color, race, educational level, and so on. However, the focus of division between class and status is different: economy is an essential factor of class but status 
values social honor factors more, such as lifestyle, consumption habits and prestige. The status in which these 'honor-style' factors compose of that determines the resulting 'identity group' of a person.

\subsubsection{Political Order: Party}

"We can understand that Weber may tend to view political parties as a means of delivering power in a distribution system.... The reason why 'party' can be seen as a hierarchical perspective is that different classes can use it to exercise power and thus change the original way of market distribution. Moreover, in the process of distribution by the market, the size of political parties' power is directly related to how much social resources they can obtain, and the power of political parties is here.”(谢泉峰, 2005)

\subsection{The Perspectives of Class Conflicts and Struggles}

As a key word of the Social Stratification Theories, the discussion about "class" could not be avoided. Since the generation of class, different classes or within one class may have conflicts due to contradiction of interest. Nevertheless, the two scholars' analysis and views on this objectively existing fact are not the same.

\subsubsection{Marx: Inevitable \& Destructive}

What Marx emphasizes is that the inequalities in the means of production have caused the capitalist society to develop two opposing classes -- the bourgeoisie and the proletariat. Then, the antithesis between them will inevitably produce class contradictions and struggles derived from the exploitation and oppression by the capitalist in terms of benefits and interests and the unbalanced development relations between the productive forces and the relations of production. Finally, the revolution will eventually erupt. Here, Marx still attributes the causes of the contradictions and struggles to the economic level and believes that as long as the institutional cause of social inequality -- capitalism exists, class contradiction and struggle will also continue. However, it will be peaceful within one class because of the complete unanimity of the fundamental interests.

According to Marx's analysis, we can also conclude that the contradictions and struggles resulting from social inequality will have an impact on the existing social order and even result in the exchange of status between the ruling class and the ruled class. At the same time, this is also the leading force that gives rise to social change.

\subsection{2: Weber: Internal \& Low Incidence}

Of course, Weber does not deny that differences in the share of resources in the market can also lead to differences between classes, but it is believed by Weber that class conflicts are more likely to occur within classes. "Because of differences in honor, there may be several completely different groups within a class, and only the same group may have the same ideology. As long as there is a difference in ideology, it is possible that conflict and struggle will occur” (谢泉峰, 2005). Here Weber puts the focus of class conflict and struggle on ideological differences, demonstrating that differences in consciousness can lead to group tension which will give rise to division within the class.

In addition, the low incidence of class struggle is believed by Weber. First, in order to guarantee and monopolize their own advantages and resources, there will be social closures set by classes, especially upper classes, so that the rates of contacting and flowing between classes will be greatly decreased, then reducing the incidence of conflict; Second, due to the ideological differences within one class, which will lead to continuous subdivision of the group, the corresponding contradiction is constantly subdivided. Therefore, class conflicts will not be able to concentrate and sharpen to a great extent, evolving into a class struggle to split the class and destroying the social structure. Besides, class struggle also requires specific social conditions as a catalyst, so the frequency of large-scale class struggles and even revolutions is very low.

\subsection{Methodology}

\subsubsection{Marx : Macro \& Objective Criticism}

According to Marx, social stratification is an objective reality that is independent of human consciousness. Therefore, Marx prefers to analyze the social stratification resulting from social inequality from a macro perspective and builds the 'two-level social model' on this basis.

The theory of social stratification developed by Marx is based on the critical historical materialism. His opinion is that the private ownership and exploitation relations in capitalist society will bring about social inequality which gives rise to class contradictions and conflicts, and the division and confrontation between classes are more likely 
to form. And this kind of struggle will eventually lead to a proletarian revolution, overturning the existing inequality. Therefore, the negative attitude of Marx about the capitalist system also extends to his negation towards social division -- the social stratification is not good.

Moreover, Marx holds a dynamic view of social stratification, pointing out that the social stratum is not fixed, but will change as the society develops. For example, with the development of social productivity, the proletariat, which gradually masters the excellent productivity will eventually overthrow the oppression and domination of the bourgeoisie through revolution, and then establishing a new classless society.

\subsubsection{Weber : Micro \& Static Humanism}

With the development of capitalist society, the middle class begin to rise and become the backbone of society. Weber sensitively captures the changes in this social structure and starts from a micro perspective, supplementing the theory of social stratification. What convinces Weber is that social stratification is not only the product of objective economics, but also the subjective consciousness built on people, and thus Weber develops the multidimensional social stratification standards centered on 'human'.

The difference from Marx is that "Weber asserts that making profits through investment, use of technology, equipment, and labor services under market conditions is the capitalist economic order which is a manifestation of the rationalization of economic life, compared with the situation of obtaining wealth and economic benefits through the means such as conquest, plunder, hereditary, feudal privilege, etc.” (刘欣, 1993). From this we can see that Weber is more inclined to rational economy structure generated by market competition in capitalism than it was in the feudal era, who regards this change as an era of progress.

In addition, there is a neutral and static attitude derived from Weber towards social stratification. He argues that between different strata and within the same stratum, the influence of the "Economic order, Social order and Political order" (Bottero, 2005) will definitely cause differences between individuals. But this kind of objective difference is one of the characteristics of the society that causes the emergence of social stratification. Therefore, Weber believes that no matter how society develops, social stratification will certainly exist. Even if there are some changes that will result in the breaking of the 'social closure' that fixes one class, another 'social closure' will immediately form. Under the different combinations of the three orders, the social stratification based on social inequality will follow, so social stratification itself is a relatively fixed order-structure in society.

In a word, the focus of Marx's theory about social stratification is class. He demonstrates that the differences in the means of production will produce the two major antagonistic classes. Then conflicts of economic interests will occur between them, which may results in the outbreak of struggles and even revolution, but we can see the same awareness and interests within one class. Because social stratification will bring social inequality and other bad effects, Marx's negative attitude can be found on it.

Nevertheless, Weber utilizes three orders: Economic order, Social order and Political order" (Bottero, 2005) as the starting point, pointing out only the combination of three orders can determine a person's stratification, not just a single division from Marx's method. Meanwhile, he also suggests that although there will be conflicts between classes, different groups can also be found within a class due to differences, such as the country and the color of the skin, thus creating different consciousness, internal conflicts and divisions in one class. Besides, Weber has a neutral and static attitude toward social stratification, who believes that differences and contradictions are normal social phenomena and will not pose a huge threat to society.

\section{THE SIMILARITIES}

Although Marx and Weber take two different analysis perspectives and focuses on 'social stratification', their theoretical research still overlaps.

\subsection{They both emphasize the role of economic factor in} social stratification.

Marx regards 'economy' as the decisive factor in class division. On accounting of there are differences in the means of production, social stratification then emerges. Although Weber believes that there are many factors that determine social stratification, however, he also agrees that 
the economic factor is an important part of the stratification standards. After all, one of the three standards that determine social stratification--class, is using the 'economy' as a reference.

\subsection{They both pay attention to ideology}

Marx's discussion of ideology can be attributed to the two concepts he proposed: 'class-in-itself' and 'class-for-itself'. In simple terms, 'class-in-itself is a passive attribution, making someone 'being' divided into a certain class, possibly because of some external criteria. 'Class-for-itself', however, is an active congregation, which reflects the recognition of class consciousness and interests by individuals who spontaneously moves closer to a class. "Only when each worker realizes that he is a member of the entire working class and his daily struggle with individual bosses and individual management is against the entire bourgeoisie and the entire government. Then their struggles can become the class struggles." (People's Publishing House, 1995)

For Weber, the class formed by economic factors is not solid enough, and only a unified ideology is capable of forming a solid group to prevent internal division. "He even thinks that 'status groups' (or 'hierarchical groups') are more mobile than 'class groups'. Because 'status groups' are intensively aware of their commonalities and the boundaries with other groups, and once this consciousness is related to race and religion with the combination of faith, it is very easy to organize collective action." (李东\&谢维和, 1987)

\section{CONCLUSION}

Marx and Weber, as masters of classical sociology, have made great contributions to the study of social stratification. Nevertheless, due to factors such as the era, methodology, and subjective judgment of individuals, their theories of social stratification is not perfect. As later students, however, we should learn to stand on the shoulders of the giants to see the problems. That means we can learn from their advantages in theoretical research and abandon their shortcomings in order to have a more comprehensive perspective for analysis.

The most important point for understanding modern society is to have a correct and scientific methodology as a guide so that we can accurately grasp its essence. Luckily, classical sociologists have provided us with different perspectives for analyzing social events, helping us to view modern society in a more 'scientific' way.

\section{REFERENCES}

[1] Xie Quanfeng. 2005. Comparison of Marx, Weber and Durkheim's Social Stratification Theory. Wuhan: Wuhan University.

[2] Yu Manhua, Bu Xiaoyong. 2017). "Marx and Weber: Comparison of Two Social Stratification Theories". Anhui: Guizhou Social Sciences.

[3] Liu Xin. 1993. "Class Status and Market Opportunities: Weber's Class Theory-A Comparison with Marx's Class Theory." Wuhan: Huazhong University of Science and Technology.

[4] Zhang Fangxu. 2011. "A Comparison of Marx and Weber's Social Stratification Theory". Shanghai: Legal System and Society.

[5] Bottero, Wendy. 2005. Stratification: Social Division and Inequality. Oxon: Routledge. 